\title{
Hydrophobic adsorption in ionic medium improves the catalytic properties of lipases applied in the triacylglycerol hydrolysis by synergism
}

\author{
José Carlos Quilles Junior ${ }^{1}$ - Ana Lúcia Ferrarezi ${ }^{2} \cdot$ Janaina Pires Borges $^{3}$.

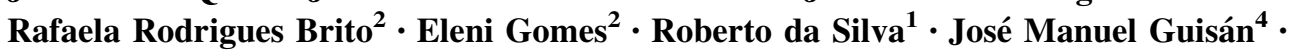 \\ Maurício Boscolo ${ }^{1}$
}

Received: 9 April 2016/Accepted: 2 August 2016/Published online: 8 August 2016

(c) Springer-Verlag Berlin Heidelberg 2016

\begin{abstract}
It is known that lipases may have their catalytic properties improved by the action of some salts or by the adsorption on hydrophobic supports. However, what we present in this work is more than that: we evaluate the combination of these two factors of hyperactivation of lipases from Acremonium-like ROG 2.1.9, a study that has not been done so far. This work proves that a synergistic effect occurs when the lipases are immobilized on hydrophobic supports at the presence of sodium chloride and are applied in triacylglycerol hydrolysis. This assay made it possible to achieve the highest hyperactivation of $500 \%$ with the lipases immobilized on Phenyl-Sepharose and applied with $0.1 \mathrm{M}$ of sodium chloride. Besides this positive effect on enzyme activity, the use of these two factors led to the thermal stability increasing of the immobilized lipases. For this derivative, the recovered activity was approximately $85 \%$ after $6 \mathrm{~h}$ incubated at $55^{\circ} \mathrm{C}$ and $1.0 \mathrm{M}$ of the sodium
\end{abstract}

José Carlos Quilles Junior

quillesjcj@gmail.com

$\triangle$ Maurício Boscolo

boscolo@ibilce.unesp.br

Ana Lúcia Ferrarezi

anafe10@yahoo.com.br

Janaina Pires Borges

janaina-pires@hotmail.com

Rafaela Rodrigues Brito

rafinha_biologia@yahoo.com.br

Eleni Gomes

eleni@ibilce.unesp.br

Roberto da Silva

dasilva@ibilce.unesp.br

José Manuel Guisán

jmguisan@icp.csic.es chloride against $50 \%$ of the same derivative without this salt. Furthermore, others assays were performed to prove the evidences about the synergistic effect, showing a promising method to improve the catalytic properties of the lipases from Acremonium-like ROG 2.1.9.

Keywords Lipases · Immobilization - Hyperactivation · Synergism · Hydrolysis

\section{Introduction}

The enzymology represents an important advance for the biotechnology industry, and the largest part of the enzymes market is occupied by hydrolytic enzymes, such as proteases, amylases, amidases, esterases, and lipases [1]. Lipases (EC 3.1.1.3 triacyl glycerol lipases) are enzymes

1 Department of Chemistry and Environmental Sciences, IBILCE/UNESP, Rua Cristóvão Colombo, 2265,

São José do Rio Preto, SP CEP 15054-000, Brazil

2 Department of Biology, IBILCE/UNESP, Rua Cristóvão Colombo, 2265, São José do Rio Preto, SP CEP 15054-000, Brazil

3 Department of Biochemistry and Chemical Technology, IQ/ UNESP, Rua Prof. Francisco Degni, 55, Araraquara, SP CEP 14800-060, Brazil

4 Department of Catalysis, CSIC (Consejo Superior de Investigaciones Científicas), Campus Universidad Autônoma, Cantoblanco, 28049 Madrid, Spain 
that catalyse both the hydrolysis of triacylglycerol and the synthesis of esters, operating on the carboxyl ester bonds of lipids [2-5]. Their catalytic site is protected by a polypeptide chain, the lid, which can be changed to its active or inactive conformation at the presence of biphasic system as oil drops, hydrophobic proteins, and gas bubble, conferring the characteristic of lipases adsorb on hydrophobic supports [6,7]. The lipases are the most important enzymes for the industry, being applied on different process, such as leather, food, cosmetic and perfume industries, food biomedical, and biosensor [8, 9]. Many biotechnology processes catalysed by enzymes are carried out under harsh conditions, requiring a biocatalyst with a high activity and stability to act under various conditions of $\mathrm{pH}$, temperature, and different concentrations of salts and organic solvents [3]. The immobilization of enzymes and cells is very useful and interesting for industrial applications [9], and it can occur on different supports through physical or chemical interactions [10]. The properties of the immobilized enzyme depend of the enzyme and type of support, because the interaction between them modulates the chemical and kinetics characters [11]. The use of immobilized enzymes has showed several advantages, such as their reuse and decrease in the cost of separation of byproducts. Hydrophobic immobilization can promote changes in the three-dimensional structure of the lipases, leading to its active conformation and exposing its active side to the reaction medium. This method was used to simultaneously immobilize and purify lipases from different microorganisms [12-14]. Hydrophobic adsorption of lipases (a physical method) can result in derivatives with hydrolytic activity higher than those immobilized by covalent bonds. Due to their non-polar characteristic, only proteins with a large non-polar chain, such as the lipases, would be able to adsorb on hydrophobic supports at low ionic strength [6, 7]. Another benefice of the physical methods is the conservation of the enzyme structure, with less or no change on the enzyme conformation [15].

Immobilized lipases on inert supports have advantages over the conventional chemicals catalysts, showing higher selectivity and activity in the operational conditions, being easily recovered of reaction medium and having lesser cost of the purification stage of products [16]. Several applications of immobilized lipases by reversible or irreversible immobilizations are reported, such as the production of long-chain polyunsaturated fatty acids (PUFAs), especially docosahexaenoic acid (DHA, C22:6n-3) and eicosapentaenoic acid (EPA, C20:5n-3) [17]; hydrolysis of vegetable oils [18-20]; regio and enantioselective reactions [21-24]; and ester production [25-28]. Other immobilization methods have been studied, as the immobilization of whole cell [29] and to improve the proprieties and efficiency of enzyme immobilization, some factors have been tested to optimize this process $[30,31]$. The development of supports for immobilization and the study of the properties of the derivatives and the supports have been investigated for some authors, reporting synergic effect on the enzymatic properties [32-35]. In some cases, the synergism was achieved by the addition of two distinct lipases in the reaction medium [36]. The synergism is an effect, where the improvement of some is more than the sum of the positive factors, in contrast to the additive fact. Thus, in this work, we proved that the hydrophobic immobilization combined with sodium chloride is an efficient and simple method to hyperactive and thermally stabilize crude lipases from Acremonium-like ROG 2.1.9 due a synergistic effect.

\section{Experiment}

\section{Materials}

The resins Phenyl-Sepharose CL-4B and Octyl-Sepharose CL-4B, used as support for immobilization, the substrate $p$ nitrophenyl butyrate ( $p$-NPB), and diethyl-p-nitrophenylphosphate (D- $p N P$ ) were purchased from SigmaAldrich (St. Louis, MO, USA). Coomassie protein assay reagent was purchased from Thermo Scientific (USA). The tested oils were obtained from local market, all the salts used of the different metallic cations with chloride were of high purity, and the other reagents were of analytical grade.

\section{Microorganism}

The lipases used for immobilization were produced from filamentous fungus Acremonium-like ROG2.1.9. This microorganism belongs to the collection of the Laboratory of Biochemistry and Applied Microbiology, from the State University of São Paulo (UNESP, Brazil) and was isolated from domestic grease trap waste. Various gene and species' identification tests were performed, and these tests were considered not conclusive. In addition, as suggested by the specialist, the name Acremonium-like ROG 19 was adopted. The data about the molecular identification of the microorganism are being treated in other paper (data not published yet).

\section{Lipase production and preparation of the extract}

Lipase production from Acremonium-like ROG 2.1.9 was carried out under solid state fermentation (SSF) in polypropylene bags $(27 \times 15 \mathrm{~cm})$ with sugar cane pulp as substrate. The inoculum corresponded to $5 \times 10^{5}$ of spores per $\mathrm{mL}$ was added in $20 \mathrm{ml}$ of a nutrient solution $(2.0 \%$ peptone, $0.2 \% \mathrm{~K}_{2} \mathrm{HPO}_{4}, 0.05 \% \mathrm{MgSO}_{4}$, w/v, and $2.0 \%$ olive oil, v/v) and maintained in fermentation bag (70\% 
v/w average moisture). Cultivation was carried out at $28{ }^{\circ} \mathrm{C}$ for $72 \mathrm{~h}$. The enzymes were extracted with $100 \mathrm{ml}$ of $5 \mathrm{mM}$ phosphate buffer $\mathrm{pH} 7.0$ and centrifuged $\left(4{ }^{\circ} \mathrm{C}\right.$, $10,000 \mathrm{rpm}, 30 \mathrm{~min})$. The supernatant was concentrated with QuixStandTM Benchtop System from Amershan Bioscience using a $10 \mathrm{kDa}$ cut-off Millipore membrane in an ultra-filtration unit, 15 psi.

\section{Lipase activity assay}

Lipase activity was determined from the hydrolysis of the chromogenic substrate $p$-NPB ( $p$-nitrophenyl butyrate), measuring the increase in the absorbance at $348 \mathrm{~nm}$ produced by the release of $p$-nitrophenol $(p \mathrm{NP})$ from the hydrolysis of $0.4 \mathrm{mM} p$-NPB in $25 \mathrm{mM}$ sodium phosphate buffer $\mathrm{pH} 7$ at $25^{\circ} \mathrm{C}$, according to the methodology described in the literature [13]. One international unit (IU) was defined as the amount of enzyme that is necessary to hydrolyse $1 \mu \mathrm{mol}$ of $p$-NPB per minute under the assay conditions described above.

\section{Hydrophobic immobilization}

Hydrophobic immobilization was carried out in $10 \mathrm{mM}$ sodium phosphate buffer $\mathrm{pH} 7.0$ using a load of $1 \mathrm{mg}$ of total protein per gram of support, for a maximum time of $180 \mathrm{~min}$. The immobilization yield (IY) was determined by checking the lipase activity on the supernatant after incubation, using Eq. 1. The amount of immobilized proteins was calculated after measuring protein concentration by a modified Bradford's method (1976). For the tests of the hydrophobic immobilization at the presence of sodium chloride, it was used in the same buffer containing 0.01, 0.1 , or $1.0 \mathrm{M}$ of $\mathrm{NaCl}$. Derivatives were washed with water and filtered under vacuum:

$\mathrm{IY}(\%)=\left(\frac{A_{o s}-A_{f s}}{A_{o s}}\right) \times 100$,

where $A_{\mathrm{os}}$ is the initial activity in the immobilization supernatant (soluble enzyme), and $A_{\mathrm{fs}}$ is the final activity after the incubation time during the immobilization process (soluble enzyme not immobilized). After the immobilization, the recovered activity (RA) of immobilized lipases was determined by Eq. 2:

$\operatorname{RA}(\%)=\left(\frac{A_{f i}}{A_{o s}}\right) \times 100$,

where $A_{\mathrm{fi}}$ is the activity of the lipases adsorbed on the support (immobilized enzyme), and $A_{\mathrm{os}}$ is the activity of the soluble lipase before the immobilization process.

\section{Effect of sodium chloride on the derivatives activity}

The derivatives were submitted to different concentrations of sodium chloride by $p$-NPB hydrolysis, using the same conditions of the assay (as described in "Lipase production and preparation of the extract".). The activity of soluble enzyme was defined as $100 \%$, and the activity of derivatives was calculated based on this value.

\section{Covalent inhibition of the lipase activity}

The lipase activity was inhibited by the incubation of the derivatives in $1 \mu \mathrm{M}$ of covalent inhibitor D- $p \mathrm{NP}$ and measured at $25{ }^{\circ} \mathrm{C}$ and $25 \mathrm{mM}$ sodium phosphate buffer pH 7.0 using $p$-NPB as substrate. As reference, we adopted the derivative produced in the absence of $\mathrm{NaCl}$, considering activity without the inhibitor as $100 \%$ [13].

\section{Thermal stability assay}

Soluble and immobilized lipases were incubated in $2 \mathrm{ml}$ of $5 \mathrm{mM}$ sodium phosphate buffer $\mathrm{pH} 7.0$ at $55{ }^{\circ} \mathrm{C}$ for $6 \mathrm{~h}$. The stability of soluble and immobilized lipases was determined by verifying the residual activity each $60 \mathrm{~min}$, using Eq. 2.

\section{Titration reaction and reutilization of the biocatalyst}

The hydrolysis reaction was performed after a screening using the soy oil as fatty acids source, using the biocatalyst with the higher hyperactivation. The reactional medium was prepared by $1.1 \%$ of Arabic gum, $37.1 \%$ of water, $49.4 \%$ of $50 \mathrm{mM}$ phosphate butter $\mathrm{pH} 7$, $12.4 \%$ of soy oil, and $10 \%$ of catalyst $(\mathrm{m} / \mathrm{m})$, incubated for $30 \mathrm{~min}$ at $37^{\circ} \mathrm{C}$ and $150 \mathrm{rpm}$. After each reaction cycle, the reaction system was filtrated to recuperate the derivate, and the liquid phase was titrated with $50 \mathrm{mM}$ sodium hydroxide solution until $\mathrm{pH}$ 8.0. The biocatalyst was washed with the hexane and used for other reaction cycle. After each cycle, this washing procedure was repeated, and the hydrolytic activity relative (HAR) was determined by

$\mathrm{HAR}=\frac{V_{(a)}-V_{(c)} \times M_{(b)} \times 1000}{m \times t}$,

where $V_{(a)}$ is the base volume used for the sample titration $(\mathrm{mL}) ; V_{(c)}$ is the base volume used for the control titration $(\mathrm{mL}) ; M_{(b)}$ is the molarity of the base used for the titration $(\mathrm{mol} / \mathrm{L}) ; \mathrm{m}$ is the total mass of the reaction medium $(\mathrm{g})$, and $t$ is the incubation time for the reaction ( $\mathrm{min}$ ). 


\section{SDS-PAGE}

Enzyme purification was analysed by SDS-PAGE according to Laemmli [44], using a precast $13 \%$ gradient gel (model protean 16; Bio-Rad Laboratories, Richmond, Calif.). Gels were silver-stained. To analyse the amount of proteins adsorbed on supports, a sample of the support was first boiled in the presence of $1 \%$ SDS (w/v) and $2 \%$ 2-mer-captoethanol (v/v) to desorb the proteins. Molecular weight markers from Bio-Rad Laboratories were used (6.5-200 kDa).

\section{Zymogram assay}

The zymogram was used to identify the Acremonium-like ROG 2.1.9 lipase. After the electrophoresis, the gel was immersed for $30 \mathrm{~min}$ in $0.05 \mathrm{M}$ phosphate buffer $\mathrm{pH} 7.5$ containing $2.5 \%$ Triton X-100 to remove SDS. The gel was subsequently incubated in a mixture of two solutions: containing $1 \mathrm{~mL}$ of acetone was dissolved in $40 \mathrm{mg}$ of $\alpha$ naphthyl acetate and $30 \mathrm{mg}$ of $\beta$-naphthyl acetate and another with $120 \mathrm{mg}$ of RR-fast-blue was dissolved in $10 \mathrm{~mL}$ of isopropanol. Both solutions were mixed and diluted with $0.1 \mathrm{M}$ phosphate buffer $\mathrm{pH} \quad 6.2-100 \mathrm{~mL}$. Molecular weight markers from GE Healthcare were used (14-90 kDa).

\section{Results and discussion}

\section{Hydrophobic immobilization and partial purification of lipases}

Hydrophobic supports are commonly applied for the immobilization and purification of lipases, due to this fact, they are considered specific for enzymes with a non-polar chain in its structure. In some cases, adsorption on these supports is enough to purify the lipases [36-41]. However, in others, additional steps may be required to obtain sample homogeneity. Lipases from Acremonium-like ROG 2.1.9 were incubated with the hydrophobic resins octyl- and phenyl-Sepharose during a maximum time of $180 \mathrm{~min}$ (Table 1). Recovered activity of immobilized lipases on both the supports was higher than the soluble enzyme, with an increase of 25 and $140 \%$ for the derivatives from octylSepharose and phenyl-Sepharose, respectively. Comparing these results, it is clear that the phenyl-Sepharose shows higher hydrophobic potential to adsorb lipases than octylSepharose. However, this resin is little studied, since there are more reports in the literature of the use octyl-Sepharose to immobilize and purify lipases from different sources. In this work, the advantages of the phenyl-Sepharose over the octyl-Sepharose are the evident, and we will focus on these benefits. An interesting fact observed from the immobilization of lipases was the specificity of the supports. OctylSepharose was more selective than phenyl-Sepharose, despite showing lower immobilization yield. This is observed by the amount of enzymes absorbed on both supports and by the factor purification showed in Table 1 . Due to its better selectivity to lipases, octyl-Sepharose is a chromatographic resin widely used in process of purification of several lipases [36-41]. SDS-PAGE in Fig. 1a shows the better purification of the total enzymes using the resin octyl-Sepharose as support. However, a cleaner extract for all purification strategies using the hydrophobic resins for lipase immobilization than the cure extract was obtained, showing that the hydrophobic immobilization is a good technic for purifying lipases. Hydrolytic zymogram was performed for identifying the hydrolysis potential of the enzymes produced by the fungi Acremonium-like ROG 2.1.9 (Fig. 1b).

The derivatives of octyl-Sepharose were more efficient in the partial purification of lipases, but this result is not associated with the activity of the immobilized enzyme. Recovered activity depends, mainly, on the immobilization mechanism and the interactions between enzyme and support. Due to the fact that the immobilization assays are performed with low protein loading, the amount of adsorbed protein did not interfere in the behaviour of lipases. We must remember that the crude enzyme extract used was rich in lipases, due the induction of the production of these enzymes during the process of fermentation of microorganism.

\section{Effect of the metallic ions on activity of soluble and immobilized lipases}

Lipases from Acremonium-like ROG 2.1.9 were incubated at $100 \mathrm{mM}$ of the different metallic ions to verify the action them on enzyme activity. It is possible to observe in Fig. 2 that the ions $\mathrm{Na}^{+}$and $\mathrm{Mn}^{+2}$ loaded to the hyperactivation of the lipases, while the others ions tested had negative effect. $\mathrm{Na}^{+}$was the ion with higher positive effect on the activity of the enzymes, showing a hyperactivation of $30 \%$. Thus, we focused the study with $\mathrm{Na}^{+}$and using sodium chloride in different concentrations; interesting results were observed on soluble and immobilized lipase activity (Fig. 3). The activity of soluble lipases was dependent of the concentration of $\mathrm{NaCl}$, showing an increase of activity in all concentrations of the tested $\mathrm{NaCl}$. The maximum peak of hyperactivation was obtained at $0.2 \mathrm{M}$ of $\mathrm{NaCl}$, with almost $90 \%$ of hyperactivation of the lipase activity. Concentrations higher than $0.2 \mathrm{M}$ of $\mathrm{NaCl}$ resulted in a decrease of activity, but even so, the activity was higher than the initial, adopted as $100 \%$. These results indicate that the lipases from Acremonium-like ROG 2.1.9 
Table 1 Partial purification of the soluble and immobilized lipases from Acremonium-like ROG 2.1.9 on octyl- (Octyl-AL) and phenyl-Sepharose (Phenyl$\mathrm{AL})$

\begin{tabular}{llllcr}
\hline Conditions $^{\mathrm{a}}$ & $\begin{array}{l}\text { Immobilization yield }^{\mathrm{b}} \\
(\%)\end{array}$ & $\begin{array}{l}\text { Total activity } \\
(\mathrm{U})\end{array}$ & $\begin{array}{l}\text { Protein } \\
(\mathrm{mg})\end{array}$ & $\begin{array}{l}\text { Specific activity } \\
(\mathrm{U} / \mathrm{mg})\end{array}$ & Purification \\
\hline Soluble enzyme & - & 1.41 & 0.19 & 1.49 & 1.00 \\
Octyl-AL & $70.4 \%$ & 1.41 & 0.05 & 52.16 & 18.08 \\
Phenyl-AL & $99.7 \%$ & 1.41 & 0.12 & 18.49 & 8.04 \\
\hline
\end{tabular}

${ }^{a}$ Condition in relation to soluble and immobilized enzyme on the different supports

b Immobilization yield after $180 \mathrm{~min}$ of incubation based on the lipase activity measured, as described in "Lipase activity assay"
Fig. 1 a SDS-PAGE stained with silver. Lanes 1 Molecular weight markers with their respective weights, 2 Immobilized proteins from Acremonium-like ROG 2.1.9 on octyl-Sepharose (Octyl-AL), 3 Supernatant of Immobilized proteins on Octyl-AL, 4 Immobilized proteins from Acremonium-like ROG 2.1.9 on phenyl-Sepharose (Phenyl-AL), 5 Supernatant of Immobilized proteins on Phenyl-AL, 6 Lipase soluble from Acremonium-like ROG 2.1.9. b Zymogram analysis. Lanes 1 Molecular weight markers with their respective weights, 2 Lipase soluble from Acremonium-like ROG 2.1.9

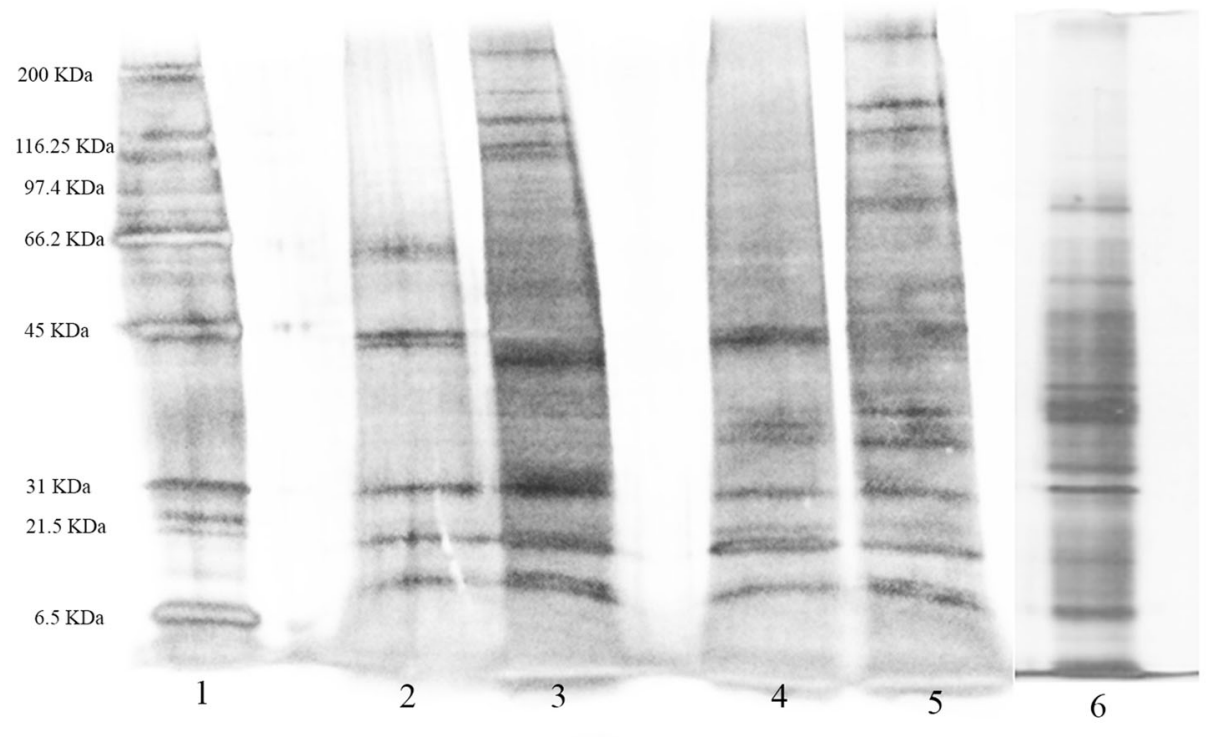

may have their activity improved by the use of $\mathrm{NaCl}$ during the catalytic processes, confirming that lipases may suffer hyperactivation at the presence of some ions [16].

Immobilized lipases by adsorption on hydrophobic supports were submitted to different concentrations of $\mathrm{NaCl}$, and the recovered activity at the absence of $\mathrm{NaCl}$ was considered as the hyperactivation of enzymes caused by hydrophobic immobilization. The effect of the hydrophobic immobilization on activity of these lipases was higher to phenyl-Sepharose than to octyl-Sepharose, showing a hyperactivation of 120 and $25 \%$, respectivelyfive times more. These results prove that the hydrophobic immobilization has positive effects on the lipase activity, mainly when the adsorption occurs on phenyl-Sepharose. Another interesting result is the effect of sodium chloride on the activity of immobilized lipases, where distinct results for the two supports were observed. Derivatives of octyl-Sepharose showed a tolerance at low concentration of $\mathrm{NaCl}$, with mild hyperactivation at $0.2 \mathrm{M}$ of this salt. The increase of the amount of sodium chloride in the reaction medium negatively affected the enzymatic activity, with recovered activity of $60 \%$ at $1.0 \mathrm{M}$ of $\mathrm{NaCl}$. However, the derivative of phenyl-Sepharose was strongly hyperactived by sodium chloride action, presenting recovered activity of almost five times in relation to enzyme soluble and twice in relation to the initial activity of the derivative. Even with the increase of concentration of $\mathrm{NaCl}$, the derivative of phenyl-Sepharose maintained its hyperactivation, with $200 \%$ of relative activity in relation to the activity of the enzyme soluble at $1.0 \mathrm{M}$ of sodium chloride. Despite the different results obtained for the hydrophobic supports tested, it was observed that the actuation of $\mathrm{NaCl}$ on the activity of the immobilized enzyme is an efficient and interesting tool to further increase the lipases hyperactivation. It shows that the combination of the use of sodium chloride in the reaction medium after hydrophobic immobilization may improve the catalytic properties of lipases from Acremonium-like ROG 2.1.9.

\section{Hydrophobic immobilization at the presence of sodium chloride}

In the absence of $\mathrm{NaCl}$, the lipases from Acremonium-like ROG 2.1.9 were adsorbed in both supports, with the immobilization yield of $100 \%$. The protein loading on octyl-Sepharose was similar in all assays without 


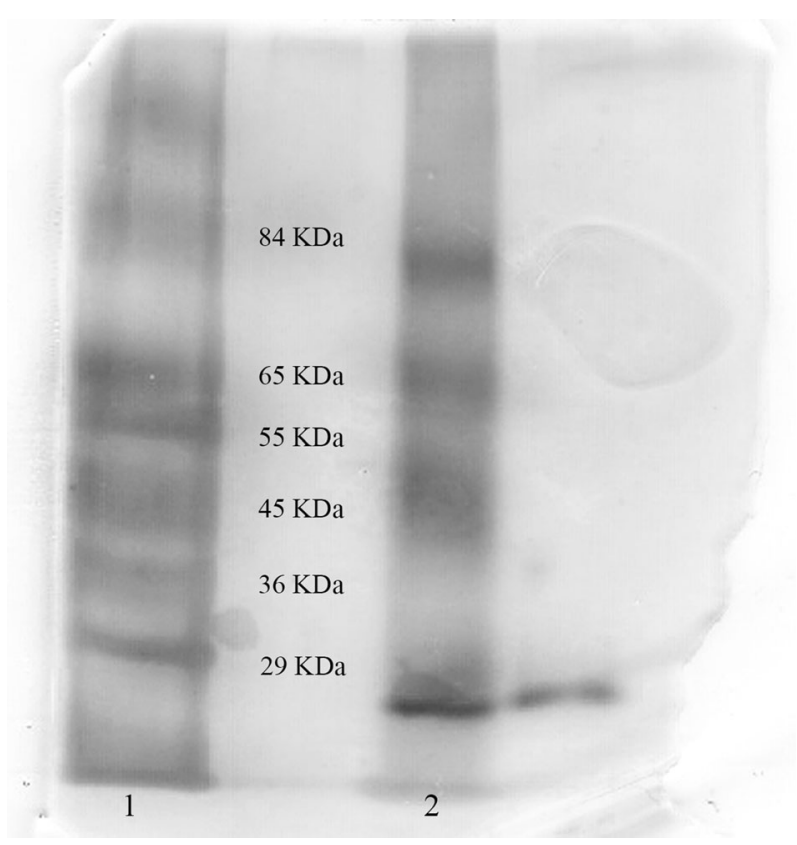

Fig. 2 Effect of metallic ions on activity of soluble lipases from Acremonium-like ROG 2.1.9. Experiments were performed in triplicate and the average of relative value $(N=3)$ and error bars are shown

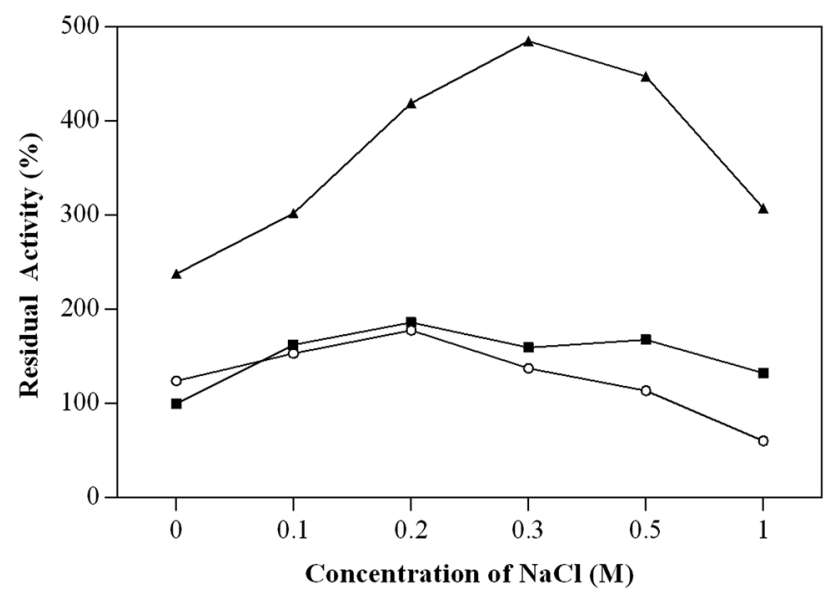

Fig. 3 Effect of sodium chloride on activity of soluble lipases from Acremonium-like ROG 2.1.9 (opened circle) and immobilized lipases on octyl-Sepharose (square) and phenyl-Sepharose (rhombus). Experiments were performed in triplicate and the average of relative value $(N=3)$ with standard error less than $5 \%$

significant changes in the immobilization yield and in the total amount of adsorbed protein. The amount of adsorbed proteins on phenyl-Sepharose was higher when the immobilization was performed with $\mathrm{NaCl}$. The increase of the ionic strength amplified the adsorption of total proteins, but it did not affect the immobilization of the lipases on support. At $1.0 \mathrm{M} \mathrm{NaCl}$, about $80 \%$ of proteins were adsorbed on phenyl-Sepharose, while $60 \%$ were adsorbed when the immobilization was performed in the absence of
$\mathrm{NaCl}$ (data not shown). The adsorption on hydrophobic supports in the absence of $\mathrm{NaCl}$ was more selective for the Acremonium-like ROG 2.1.9 lipases in both supports, and however, the process performed in the presence of $\mathrm{NaCl}$ was more effective for the hyperactivation of these enzymes.

The hyperactivation of the immobilized lipases was observed in both derivatives, with maximum of $120 \%$ to the phenyl-Sepharose and $62 \%$ to the octyl-Sepharose, both of them at $0.01 \mathrm{M} \mathrm{NaCl}$ (Table 2). Hyperactivation of lipases on hydrophobic supports is observed when the immobilization occurs through the lid of the enzyme, rendering derivatives that maintain the active conformation of the enzyme preserved. This phenomenon has been already observed for lipases from Candida rugosa (110\%), Candida antarctida (200\%), Thermomyces lanuginosus (2000\%), M. javanicus (300\%), Rhizomucor miehei (700\%), P. flourescens (150\%), R. niveus (600\%), and porcine pancreas $(300 \%)$ when immobilized on octylSepharose with high hyperactivation in the hydrolysis of $p$ NPP [16]. Adsorption of lipases on phenyl-Sepharose and its application in reactions is still poorly studied. However, results showed that its utilization for hydrophobic immobilization contributed for the hydrolytic activity of lipases from Acremonium-like ROG 2.1.9. In this way, the adsorption of these lipases on hydrophobic supports in the presence of ionic strength caused the hyperactivation of immobilized enzymes for all derivatives of phenylSepharose when compared with the same derivative in the absence of $\mathrm{NaCl}$. We hypothesized that the immobilization on phenyl-Sepharose at $0.01 \mathrm{M} \mathrm{NaCl}$ favoured the hydrolytic activity of lipases by preserving and stabilizing its active structure and also promoting high activity. Usually, lipases do not require cofactors; however, some ion may promote the hyperactivation of the enzyme, such as the lipase from Staphylococcus sp that showed an influence of the $\mathrm{Ca}^{+2}$ ions for its activity [36]. These results show a relevant and new characteristic of the lipase studied when exposed to concentrations of sodium chloride during the hydrophobic immobilization, with a positive influence in its activity by this salt.

\section{Effect of the sodium chloride on the activity of lipases immobilized in the presence of sodium chloride}

For understanding the effect of $\mathrm{NaCl}$ in the lipase activity, the evaluation of the immobilized enzyme activity using a catalytic medium with this salt was performed. Immobilized lipases on octyl- and phenylSepharose in the presence of $\mathrm{NaCl}(0.01 \mathrm{M})$ were submitted to different reaction medium conditions, and the results are shown in Fig. 4. For all the conditions of salt 
Table 2 Relative activity (\%) of soluble and immobilized lipases from Acremonium-like ROG 2.1.9 at different conditions

\begin{tabular}{|c|c|c|c|}
\hline \multirow[t]{2}{*}{ Assay conditions } & \multicolumn{3}{|c|}{ Relative activity $(\%)$} \\
\hline & Soluble enzyme & Phenyl-AL & Octyl-AL \\
\hline Absence $\mathrm{NaCl}$ & 100 & 240 & 125 \\
\hline Presence of $\mathrm{NaCl}^{*}$ & 190 & 500 & 156 \\
\hline Immobilized lipase in the presence of $\mathrm{NaCl}$ and assayed in the absence $\mathrm{NaCl}$ & - & 220 & 162 \\
\hline Immobilized lipases in the presence of $\mathrm{NaCl}$ and assayed in the presence of $\mathrm{NaCl}$ & - & 270 & 320 \\
\hline
\end{tabular}

The experiments were performed on triplicate with the standard error less than $5 \%$

* Concentration of sodium chloride was obtained in the maximum hyperactivation for derivatives and soluble enzyme

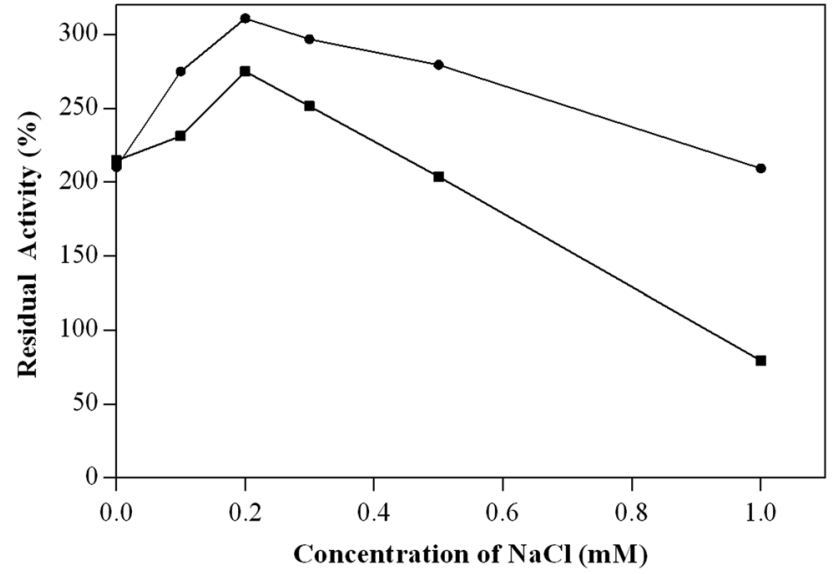

Fig. 4 Effect of sodium chloride on the activity of the immobilized lipases at the presence of $0.01 \mathrm{M}$ of $\mathrm{NaCl}$ on octyl-Sepharose (square) and phenyl-Sepharose (circle). The experiments were performed on triplicate with the standard error less than $5 \%$

tested, the activity of supernatant was measured to ensure that there was not desorption of the immobilized lipases from the supports (data not shown). All the studied derivatives suffered hyperactivation in the presence of $\mathrm{NaCl}$, but distinct results were obtained for these two supports. Immobilized lipases on octyl-Sepharose at $0.01 \mathrm{M}$ of $\mathrm{NaCl}$ were more active and resistant in all concentration of $\mathrm{NaCl}$ used, with a maximum hyperactivation of $200 \%$ in $0.3 \mathrm{M}$ of sodium chloride, regarding the soluble enzyme. However, contrary results were obtained using the phenyl-Sepharose as support in the immobilization of these lipases. For this support, the derivative immobilized at $0.1 \mathrm{M}$ of $\mathrm{NaCl}$ had its activity inhibited by increasing of concentration of $\mathrm{NaCl}$, keeping $60 \%$ of relative activity at $1.0 \mathrm{M}$ of sodium chloride. Thus, for the derivative of octyl-Sepharose, the presence of $\mathrm{NaCl}$ may be used during the hydrophobic immobilization and applied in the reaction medium to increase the performance of lipases from Acremonium-like ROG 2.1.9, assisting in the hyperactivation of enzymes with better catalytic characteristics.

\section{Study of the hyperactivation mechanism: synergy effects}

Analysing the results obtained by hydrophobic immobilization and the effects of the sodium chloride, we can expect additive effects in the activity of lipases, leading to higher hyperactivation. However, Table 2 resumes the results and it is not observed the addition of these effects, but thus a higher activity than expected. The activity of soluble enzyme was hyperactived to $190 \%$ at the presence of $\mathrm{NaCl}$, while the hydrophobic immobilization increased to enzyme activity in 240 and $125 \%$ for phenyl- and octylSepharose, respectively. Based on this, the addition of these two effects on activity of lipases from Acremonium-like ROG 2.1.9 would be lesser than the maximum hyperactivation obtained using these two supports. This suggests that the hyperactivation caused by hydrophobic immobilization and the use of sodium chloride has different action mechanism: they are not summative, but synergy effects. In general, it is known that the hyperactivation of lipases occurs, mainly, by the opening of the lid and active side exposition to reaction medium. Thus, it is common the use of hydrophobic surfaces or drops of non-polar substances to stabilize the enzyme in its active conformation. However, we can prove that the use of hydrophobic supports and the action of sodium chloride have a positive effect in the stabilization of the opened conformation of the lipases, promoting conformational changes and different exact shapes of the opened form of lipases. This modified open form may be adsorbed on hydrophobic supports yielding new stabilized immobilized open form of lipases with higher activity, selectivity, and stability, based on an important mechanism of the synergism (Fig. 5). Other important observation is that the lipases have tendency to form aggregates when are in solution [42,43], and due to this, aggregates may be immobilized in the inactive conformation. Based on the salt in effect, low alterations in the ionic strength are a great method to solvate proteins. Consequently, an increase in the protein solubility and decrease the interaction protein- 


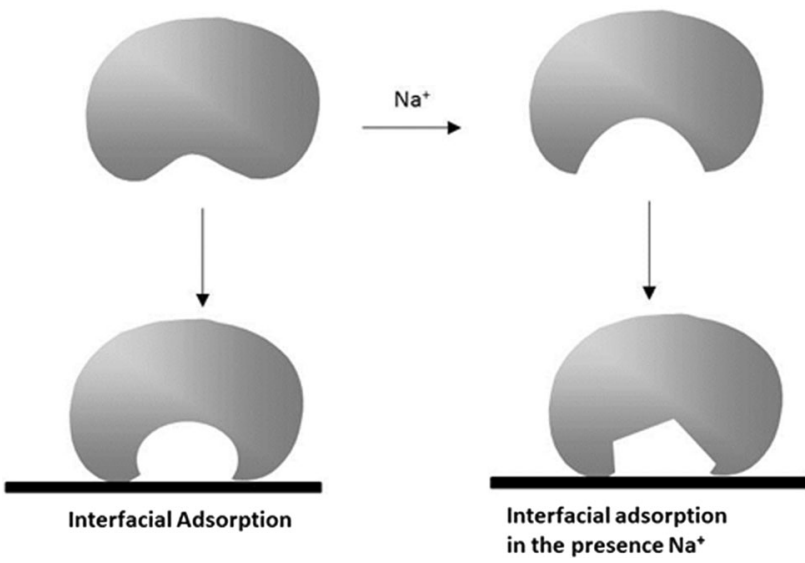

Fig. 5 Suggest mechanism of lipase immobilization on hydrophobic supports using the ionic condition $(\mathrm{NaCl})$. Lipase immobilization by hydrophobic adsorption occurs by the interaction between the lid and the support, what confers to enzyme its open and active conformation. The presence of $\mathrm{Na}^{+}$ions promotes a better stabilization and modulation of the active side what confers a higher enzymatic properties

protein occurs, what can confer lower aggregates in solution and better immobilization of active form and this may explain the higher synergistic effect at low concentration of $\mathrm{NaCl}$. However, Entressangles and Desnuelle (1968) showed that the synergism by the use of $\mathrm{NaCl}$ in hydrolysis reaction may be due the association of the oil molecules, on which the lipases are active. Thus, the lipases are able to promote the hydrolysis of both aggregates and emulsified molecules of substrates, what this may be other propose to the effect of the $\mathrm{NaCl}$.

\section{Covalent inhibition}

The D- $p N P$ used as an inhibitor acts on serine residues present on the active side of lipases, resulting in the enzymatic inactivation. Hydrophobic immobilization can promote the stabilization of the lipase in its active conformation, and the inhibition occurs easier and faster in this condition. This study was performed with derivatives that showed higher hydrolysis activity and the same derivatives immobilized in the absence of $\mathrm{NaCl}$, adopted as reference. The inhibition course of octyl-Sepharose derivatives immobilized in the absence of $\mathrm{NaCl}$ and $0.01 \mathrm{M}$ of this salt was similar after 5 min (Fig. 6). However, the low concentration of $\mathrm{NaCl}$ added to the medium of immobilization on phenyl-Sepharose showed to be a significant factor to increase the activity of lipases, promoting a novel active site, more active and open. This is possible due to the direction of the hydrophobic chain to support and the availability of the active site to the reaction medium, immobilizing higher amount of enzymes in the active form than the normal immobilization conditions. In these conditions, the covalent inhibitor reacts more easily with the

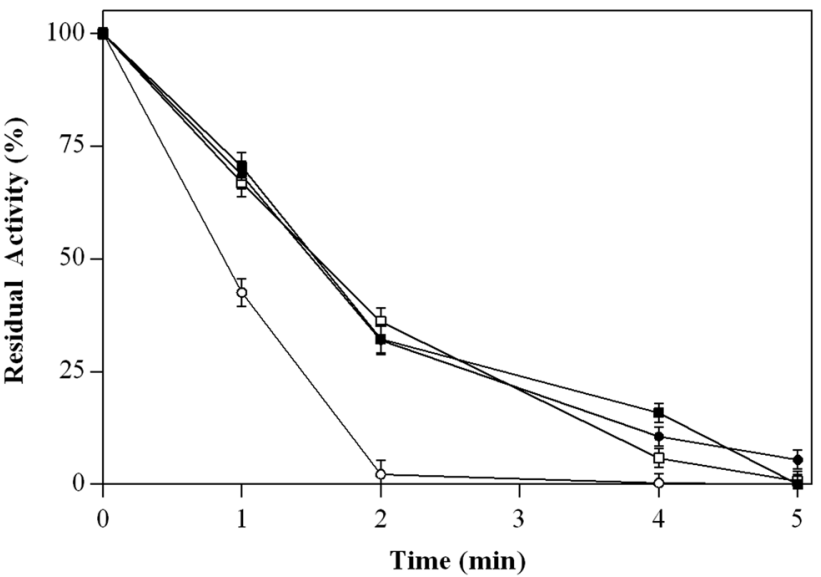

Fig. 6 Covalent inhibition with D-pNP of the different derivatives of the lipases from Acremonium-like ROG 2.1.9. Closed square octylSepharose without $\mathrm{NaCl}$. Opened square octyl-Sepharose $0.01 \mathrm{M}$ $\mathrm{NaCl}$. Closed circle phenyl-Sepharose without $\mathrm{NaCl}$. Opened circle phenyl-Sepharose $0.01 \mathrm{M} \mathrm{NaCl}$. Experiments were performed in triplicate and the average of relative value $(N=3)$ and error bars are shown

active site and causes enzymatic inactivation faster than the others derivatives of phenyl-Sepharose immobilized at $0.01 \mathrm{M}$ of $\mathrm{NaCl}$.

\section{Positive effect of the $\mathrm{NaCl}$ on thermal stability of the immobilized lipases}

Thermal inactivation was performed at $55{ }^{\circ} \mathrm{C}$ during a maximum time of $6 \mathrm{~h}$ (Fig. 7). The soluble lipase showed a half-life of $20 \mathrm{~min}$, and after $60 \mathrm{~min}$, it was completely inactive. All the derivatives were more stable than the soluble enzyme, with minimum half-life of $3 \mathrm{~h}$. This shows that the hydrophobic immobilization may provide a stable and effective link between enzyme and support, conferring more stability to structure enzyme.

The recovered activity of the derivatives of octylSepharose after the incubation time was very similar, within the standard error. After $2 \mathrm{~h}$, the derivative of $1 \mathrm{M}$ $\mathrm{NaCl}$ showed activity higher than all other derivatives, but its activity was strongly inhibited by the incubation period. During the incubation time, the derivative immobilized at the absence of $\mathrm{NaCl}$ showed lesser stability than the derivatives immobilized at the presence of $\mathrm{NaCl}$. The same was observed with the derivatives of phenyl-Sepharose, in which after $6 \mathrm{~h}$ of incubation, $80 \%$ of the activity was obtained for the derivative immobilized at $1.0 \mathrm{M} \mathrm{NaCl}$, followed by derivatives immobilized at $0.1 \mathrm{M}(75 \%)$ and $0.01 \mathrm{M}(70 \%)$. This behaviour shows that the thermal stability was amplified with the increase of concentration of $\mathrm{NaCl}$, suggesting that the immobilization at high ionic strength may contribute considerably to the thermal stability of the lipases from Acremonium-like ROG 2.1.9. 
During the incubation time at $55{ }^{\circ} \mathrm{C}$, it was evident that the presence of $\mathrm{NaCl}$ in the immobilization process was more effective to immobilization on phenyl-Sepharose than on octyl-Sepharose. The derivatives of phenyl-Sepharose immobilized at the presence of $\mathrm{NaCl}$ were markedly more
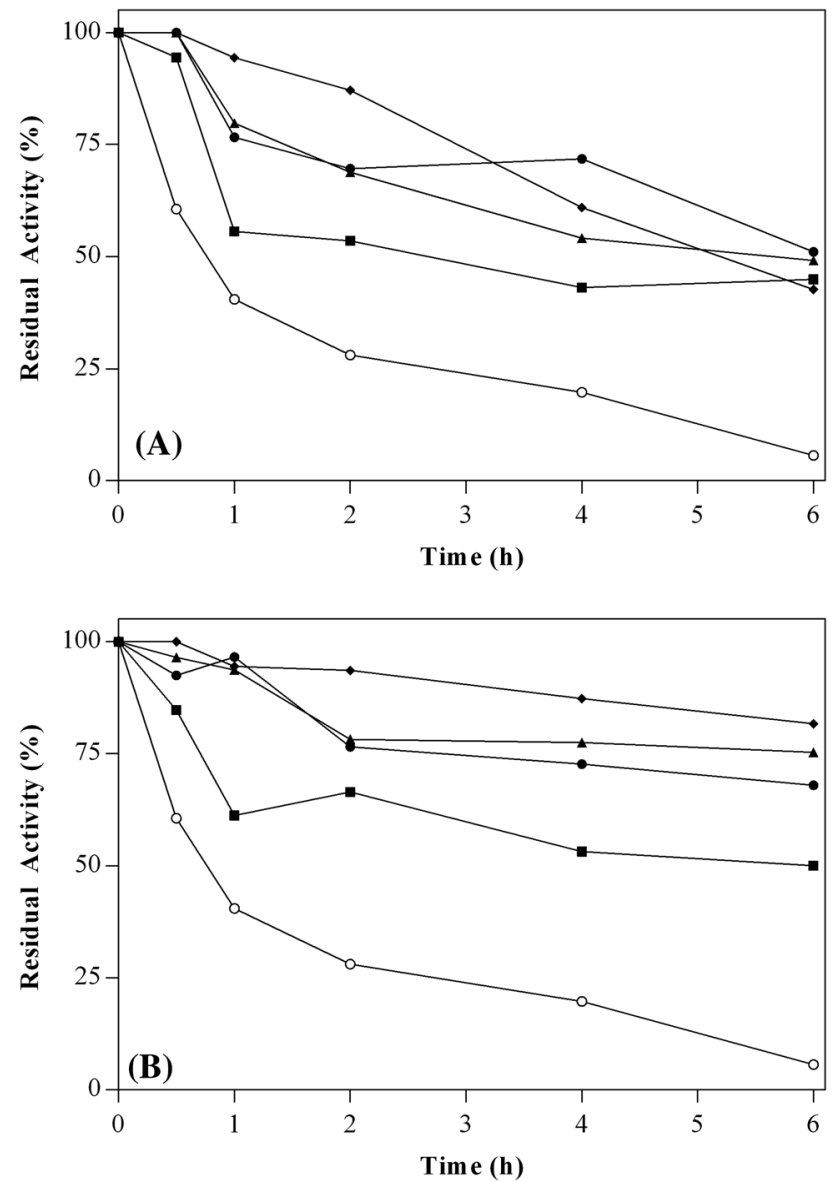

Fig. 7 Thermal inactivation at $55{ }^{\circ} \mathrm{C}$ of lipases from Acremoniumlike ROG 2.1.9 soluble and immobilized on octyl- (a) and phenylSepharose (b) at different ionic strengths. Opened circle soluble enzyme. Square without $\mathrm{NaCl}$. Closed circle $0.01 \mathrm{M} \mathrm{NaCl}$. Triangles $0.1 \mathrm{M} \mathrm{NaCl}$. Rhombus $1 \mathrm{M} \mathrm{NaCl}$. The experiments were performed in triplicate with the standard error less than $5 \%$ stable during all the incubation time. This is further evidence that the immobilization on octyl-Sepharose is not influenced by strength ionic, without affecting the activity and stability of immobilized lipases. Thus, the concentration of $\mathrm{NaCl}$ may modulate the enzyme to a stable structure, preserving its catalytic activity and increasing the thermal stabilization, mainly to the phenyl-Sepharose derivatives.

\section{Reutilization of the biocatalyst}

Hydrolysis of the soy oil was performed using the biocatalyst with the higher hyperactivation with $\mathrm{NaCl}$ and compared to the same biocatalyst immobilized without $\mathrm{NaCl}$ and the results are shown in Table 3. Using the same protein loading for both immobilization conditions, different results were obtained, in which the use of $0.01 \mathrm{M}$ of $\mathrm{NaCl}$ was fundamental for the improvement of the lipase activity more than five times (Table 3). Other positive observation about the use of $\mathrm{NaCl}$ during the immobilization process was the stability of the immobilized lipase, with the maximum of reuse in four reaction cycles, while the derivative immobilized without this salt cation did not show activity in the second cycle. These results show that the use of $\mathrm{NaCl}$ during the hydrophobic immobilization was an important fact to increase the hydrolytic activity and stability of these lipases. The total loose of hydrolytic activity of the enzymes after some reaction cycles may be caused by desorption of the enzymes from the support, during the washing process. This problem was decreased by the $\mathrm{Na}^{+}$cations action, showing a derivate more active and stable for application in the hydrolysis of triacylglycerol.

\section{Conclusions}

Hydrophobic immobilization at the presence of low amount of $\mathrm{NaCl}$ was an interesting strategy to improve the mechanical and catalytic properties of lipases from

Table 3 Hydrolysis activity determined by the titration assay of the immobilized lipases from Acremonium-like ROG 2.1.9 at $\mathrm{NaCl} 0.01 \mathrm{M}$ and without this salt and reutilization cycles

\begin{tabular}{|c|c|c|c|c|c|c|c|}
\hline \multirow[t]{2}{*}{ Derivative } & \multirow{2}{*}{$\begin{array}{l}\text { Protein loading } \\
\text { (mg/g support) }\end{array}$} & \multicolumn{2}{|c|}{ Hydrolytic activity } & \multicolumn{4}{|c|}{ Reutilization cycles $^{\mathrm{d}}$} \\
\hline & & $\mathrm{U} / \mathrm{g}^{\mathrm{b}}$ & Relative $(\%)^{\mathrm{c}}$ & Cycle 1 & Cycle 2 & Cycle 3 & Cycle 4 \\
\hline Phenyl-AL & 0.4882 & 0.955 & 100 & 100 & 8.9 & * & $*$ \\
\hline Phenyl-AL with $\mathrm{NaCl} 0.01 \mathrm{M}$ & 0.4803 & 5.136 & 537.2 & 100 & 100 & 80.1 & 10.4 \\
\hline
\end{tabular}

The experiments were performed on triplicate with the standard error less than $5 \%$

* Activity not detected

${ }^{a}$ Protein loading was measured by the Bradford assay of the supernatant after the immobilization

b Hydrolytic activity (U/g) was determined using Eq. 3

${ }^{c}$ Hydrolytic activity relative (\%) was determined considering the activity of the derivative Phenyl-AL immobilized without NaCl as $100 \%$

${ }^{\mathrm{d}}$ Reutilization cycle was performed as described in the section. The activity of the firs cycle was considered as $100 \%$ for each derivate 
Acremonium-like ROG 2.1.9. Both the supports tested were influenced by this synergistic effect promoting, mainly, higher mechanical stability and activity for both synthetic and natural substrate hydrolysis. Furthermore, this work shows that two factors that cause the increase of enzymatic activity separately when are used together take to synergism that modulates the enzymatic active site and cause the hyperactivation of these lipases, being a promising tool for biotechnology application.

Acknowledgments The authors thank the financial support from São Paulo Research Foundation (FAPESP), Grants 2012/09054-3 and 2013/00530-0 and to Dr. André Rodrigues, expert systematics of fungi and researcher at the State University of São Paulo (UNESP, Rio Claro, SP, Brazil).

\section{References}

1. Gupta S, Ingole P, Singh K, Bhattacharya A (2012) Comparative study of the hydrolysis of different oils by lipase-immobilized membranes. J Appl Polym Sci 124:17-26

2. Chen GJ, Kuo CH, Chen CI, Yu CC, Shieh CJ, Liu YC (2012) Effect of membranes with various hydrophobic/hydrophilic properties on lipase immobilized activity and stability. J Biosci Bioeng 113:166-172

3. Pérez D, Martín S, Fernández-Lorente G, Felice M, Guisán JM, Ventosa A, García MT, Mellado E (2011) A novel halophilic lipase, LipBL, showing high efficiency in the production of eicosapentaenoic acid (EPA). PLoS One 6:1-11

4. Secundo F, Correa G, Tarabiono C, Gatti-Lafranconi P, Brocca S, Lotti M, Jaeger KE, Puls M, Eggert T (2006) The lid is a structural and functional determinant of lipase activity and selectivity. J Mol Catal B Enzym 39:166-170

5. Quilles JCJ, Brito RR, Borges JP, Aragon CC, Fernandez-Lorente G, Bocchni-Martins DA, Gomes E, da Silva R, Boscolo M, Guisán JM (2015) Modulation of the activity and selectivity of the immobilized lipases by surfactants and solvents. Biochem Eng J 93:274-280

6. Mateo C, Palomo JM, Fernandez-Lorente G, Guisan JM, Fernandez-Lafuente R (2007) Improvement of enzyme activity, stability and selectivity via immobilization techniques. Enzyme Microb Technol 40:1453-1463

7. Manol EA, Santos JCS, Freire DMC, Rueda N, Fernandez-Lafuente R (2015) Immobilization of lipases on hydrophobic supports involves the open form of the enzyme. Enzyme Microb Technol 71:53-57

8. Siodmiak T, Mangelings D, Heyden YV, Borowska MZ, Marszall MP (2015) High enantioselective novozym 435-catalyzed esterification of $(\mathrm{R}, \mathrm{S})$-flurbiprofen monitored with a chiral stationary phase. Appl Biochem Biotechnol 175:2769-2785

9. Ashajari M, Mohammadi M, Badri R (2015) Chemical amination of Rhiopus oryzae lipase for multipoint covalent immobilization on epoxy-functionalized supports: modulation of stability and selectivity. J Mol Catal B Enzym 115:128-134

10. Tavano OL, Fernandez-Lafuente R, Goulart AJ, Monti R (2013) Optimization of the immobilization of sweet potato amylase using glutaraldehyde-agarose support. Characterization of the immobilized enzyme. Process Biochem 48:1054-1058

11. Sheldon RA (2007) Enzyme Immobilization: the quest for optimum performance. Adv Synth Catal 349:1289-1307
12. Romero O, Ribero CW, Guisan JM, Palomo JM (2013) Novel enzyme-polymer conjugates for biotechnological applications. Peer J 27:1-17

13. Fernandez-Lafuente R, Armisen P, Sabuquillo P, FernandezLorente G, Guisan JM (1998) Immobilization of lipases by selective adsorption on hydrophobic supports. Chem Phys Lipids 93:185-197

14. Kurtovic I, Marshall SN, Zhao X (2011) Hydrophobic immobilization of a bile salt activated lipase from Chinook salmon (Oncorhynchus tshawytscha). J Mol Catal B Enzym 72:168-174

15. Zivkovic LTI, Zivkovi LS, Balic BM, Kokunesoski MJ, Jokic BM, Karadzic IM (2015) Immobilization of Candida rugosa lipase by adsorption onto biosafe meso/macroporous silica zirconia. Biochem Eng J 93:73-83

16. Coteron A, Martinez M, Aracil J (1998) Reactions of olive oil and glycerol over immobilized lipases. J Am Oil Chem Soc 75:657-660

17. Arab-Tehrany E, Jacquot M, Gaiani C, Imran M, Desobry S, Linder M (2012) Beneficial effects and oxidative stability of omega-3 long-chain polyunsaturated fatty acids. Trends Food Sci Technol 25:24-33

18. Mendes AA, Castro HF, Rodrigues DS, Adriano WS, Tardiolli PW, Mammarella EJ, Giordano RC, Giordano RLC (2011) Multipoint covalent immobilization of lipase on chitosan hybrid hydrogels: influence of the polyelectrolyte complex type and chemical modification on the catalytic properties of the biocatalysts. J Ind Microbiol Biotechnol 38:1055-1066

19. Rooney D, Weatherley LR (2001) The effect of reaction conditions upon lipase catalysed hydrolysis of high oleate sunflower oil in a stirred liquid-liquid reactor. Process Biochem 2001(36):947-953

20. Santos KC, Cassimiro DMJ, Avelar MHM, Hirata DB, Castro HF, Fernández-Lafuente R, Mendes AA (2013) Characterization of the catalytic properties of lipases from plant seeds for the production of concentrated fatty acids from different vegetable oils. Ind Crops Prod 49:462-470

21. Palomo JM, Segura RL, Fernández-Lorente G, Fernández-Lafuente R, Guisán JM (2007) Glutaraldehyde modification of lipases adsorbed on aminated supports: a simple way to improve their behaviour as enantioselective biocatalyst. Enzyme Microb Technol 40:704-707

22. Wei HN, Wu B (2008) Screening and immobilization Burkholderia sp. GXU56 lipase for enantioselective resolution of (R, S)-methyl mandelate. Appl Biochem Biotechnol 149:79-88

23. Kaewprapan K, Wongkongkatep J, Panbangred W, Phinyocheep P, Marie E, Durand A, Inprakhon P (2011) Lipase-catalyzed synthesis of hydrophobically modified dextrans: activity and regioselectivity of lipase from Candida rugose. J Biosci Bioeng 112:124-129

24. Matsumae H, Furui M, Shibatani T, Tosa T (1994) Production of optically active 3-phenylglucidic acid ester by the lipase from Serratia marcescens on a hollow-fiber membrane reactor. J Ferment Bioeng 78:59-63

25. Jegannathan KR, Jun-Yee L, Chan ES, Ravindra P (2009) Design an immobilized lipase enzyme of biodiesel production. J Renew Sustain Energy 1:1-8

26. Li X, He XY, Li LZ, Wang YD, Wang CY, Shi H, Wang F (2012) Enzymatic production of biodiesel from Pistacia chinensis bge seed oil using immobilized lipase. Fuel 92:89-93

27. Lu J, Deng L, Nie K, Wang F, Tan T (2012) Stability of immobilized Candida sp. 99-125 lipase for biodiesel production. Chem Eng Technol 35:2120-2124

28. Azócar L, Ciudad G, Heipieper HJ, Muñoz R, Navia R (2011) Lipase-catalyzed process in an anhydrous medium with enzyme reutilization to produce biodiesel with low acid value. J Biosci Bioeng 112:583-589 
29. Hama S, Tamalampudi S, Fukumizu T, Miura K, Yamaji H, Kondo A, Fukuda A (2008) Lipase localization in Rhizopus oryzae cells immobilized within biomass support particles for use as whole-cell biocatalyst in biodiesel-fuel production. J Biosci Bioeng 101:328-333

30. Wang A, Liu M, Wang H, Zhou C, Du Z, Zhu S, Shen S, Ouyang $P$ (2008) Improving enzyme immobilization in mesocellular siliceous foams by microwave irradiation. J Biosci Bioeng 106:286-291

31. Trivedi A, Heinemann M, Spiess AC, Daussmann T, Buchs J (2005) Optimization of adsorptive immobilization of alcohol dehydrogenases. J Biosci Bioeng 99:340-347

32. Jun C, Jeon BW, Joo JC, Lee QAT, Gu SA, Byun S, Cho DH, Kim D, Sang BI, Kim YH (2013) Thermostabilization of Candida antarctica lipase B by double immobilization: adsorption on a macroporous polyacrylate carrier and R1 silaffin-mediated biosilicification. Process Biochem 48:1181-1187

33. Cui C, Tao Y, Ge C, Zhen Y, Chen B, Tan T (2015) Synergistic effects of amine and protein modified epoxy-support on immobilized lipase activity. Colloids Surf B 133:51-57

34. Vasconcellos A, Paula AS, Luizon RAF, Farias LA, Gomes E, Aranda DAG, Nery JG (2012) Synergistic effect in the catalytic activity of lipase Rhizomисо miehei immobilized on zeolites for the production of biodiesel. Microporous Mesoporous Mater 163:343-355

35. Ibrahim NA, Guo Z, Xu X (2008) Enzymatic interesterification of palme stearin and coconut oil by a dual lipase system. J Am Oil Chem Soc 85:37-45

36. Cherif S, Mnif S, Hadrich F, Adbelkafi S, Sayadi S (2008) A newly high alkaline lipase: an ideal choice for application in detergent formulations. Lipids Health Dis 10:1-8

37. Fernandez-Lorente G, Palomo JM, Cocca J, Mateo C, Moro P, Terreni M, Fernandez-Lafuente R, Guisan JM (2003) Regio- selective deprotection of peracetylated sugars via lipase hydrolysis. Tetrahedron 59:5705-5711

38. Fernández-Lorente G, Betancor L, Carrascosa AV, Palomo JM, Guisán JM (2012) Release of omega-3 fatty acids by the hydrolysis of fish oil catalyzed by lipases immobilized on hydrophobic supports. J Am Oil Chem Soc 89:97-102

39. Galvis M, Barbosa O, Ruiz M, Cruz J, Ortiz C, Torres R, Fernandez-Lafuente R (2012) Chemical amination of lipase B from Candida antarctica is an efficient solution for the preparation of crosslinked enzyme aggregates. Process Biochem 47:2373-2378

40. Brabcová J, Demianová Z, Vondrasek J, Jágr M, Zarevúcka M, Palomo JM (2013) Highly selective purification of three lipases from Geotrichum candidum 4013 and their characterization and biotechnological applications. J Mol Catal B Enzym 98:62-72

41. Abreu L, Fernandez-Lafuente R, Rodrigues RC, Volpato G, Ayub MAZ (2014) Efficient purification-immobilization of an organic solvent-tolerant lipase from Staphylococcus warneri EX17 on porous styrene-divinylbenzene beads. J Mol Catal B Enzym 99:51-55

42. Barbosa O, Torres R, Ortiz C, Fernandez-Lafuente R (2012) The slow-down of the CALB immobilization rate permits to control the inter and intra molecular modification produced by glurataldehyde. Process Biochem 47:766-774

43. Ferrarezi AL, Pivetta DH, Bonilla-Rodriguez GO, Silva R, Guisán JM, Gomes E, Pessela BC (2013) Partial purification, immobilization and preliminary biochemical characterization of lipases from Rhizomucor pusillus. Adv Enzyme Res 1:79-90

44. Laemmli UK (1970) Cleavage of structural proteins during the assembly of the head of bacteriophage T4. Nature 277:680-685 